\title{
Viabilitas Oosit Domba Pasca Vitrifikasi menggunakan Kombinasi Ethilen Glikol dan Dimetil Sulfoksida dengan Dua Level Konsentrasi yang Berbeda
}

\author{
T. Gita ${ }^{1 a}$, R. Widyastuti' ${ }^{2}$ M. R. A. A. Syamsunarno ${ }^{3}$ \\ ${ }^{1}$ Program Studi Kedokteran Hewan, Fakultas Kedokteran, Universitas Padjadjaran \\ ${ }^{2}$ Laboratorium Reproduksi dan Inseminasi Buatan, Departemen Produksi Ternak, Fakultas Peternakan, Universitas \\ Padjadjaran \\ ${ }^{3}$ Departemen Ilmu Kedokteran Dasar, Fakultas Kedokteran, Universitas Padjadjaran \\ ${ }^{a}$ Email: tyagita.hartady@gmail.com
}

\begin{abstract}
Abstrak
Vitrifikasi merupakan metode kriopreservasi untuk membekukan sel secara cepat, tanpa disertai terbentuknya kristal es. Vitrifikasi dilakukan dengan menggunakan krioprotektan yang memiliki toksitas rendah sehingga oosit dapat mempertahankan viabilitasnya. Dimetil sulfoksida (DMSO) dan ethylene glycol (EG) merupakan krioprotektan intraseluler dengan toksisitas rendah sehingga kombinasi kedua krioprotektan tersebut diharapkan dapat meningkatkan viabilitas oosit pasca vitrifikasi. Tujuan dari penelitian ini adalah untuk mengevaluasi viabilitas oosit pasca vitrifikasi dengan menggunakan kombinasi DMSO dan EG pada konsentrasi yang berbeda. Penelitian dilaksanakan di Laboratorium Riset dan Bioteknologi, Fakultas Peternakan, Universitas Padjadjaran periode September 2016-Desember 2016. Penelitian menggunakan Rancangan Acak Lengkap dengan dua kelompok perlakuan, yaitu media vitrifikasi dengan dua konsentrasi yang berbeda: $15 \%$ DMSO+15\% EG dan media 17\% DMSO+17\%EG. Setelah seminggu penyimpanan, maka dilakukan proses warming untuk mengevaluasi viabiltias oosit pasca vitrifikasi. Hasil Penelitian menunjukkan bahwa viabilitas oosit yang divitrifikasi dengan menggunakan $17 \%$ DMSO $+17 \%$ EG nyata lebih tinggi apabila dibandingkan dengan $15 \%$ DMSO $+15 \%$ EG.
\end{abstract}

Kata kunci: vitrifikasi, Dimetil sulfoksida, Ethylen glikol, viabilitas oosit

\section{Sheep Oocyte Viability after Vitrification using Two Level Different Concentration Combination of Ethylene Glycol and Dimethyl Sulfoxida}

\begin{abstract}
Vitrification is a cryopreservation method to freeze cell rapidly without ice crystallization. Vitrification is done using cryoprotectant with a low toxicity so the oocyte is able to maintain its viability. Dimethyl sulfoxide (DMSO) and ethylene glycol (EG) are intracellular cryoprotectants with low toxicity so the combination of both cryoprotectants is expected to increase post-vitrification oocyte viability. The objectives of this study were to evaluate the viability of post-vitrification oocytes by using a combination cryoprotectant of EG and DMSO at different concentrations. The research was conducted at Research and Biotechnology Laboratory, Faculty of Animal Husbandry, Padjadjaran University period September 2016-December 2016. The study used the Complete Randomized Design with two treatment groups, two vitrification medias with two different concentrations, 15\% DMSO+15\% EG and 17\% DMSO+17\%EG. After a week of storage, a warming process was performed to evaluate the viability of post-vitrification oocytes. The results showed that the viability of the vitrified oocytes using $17 \%$ DMSO+17\% EG was significantly higher when compared with $15 \%$ DMSO $+15 \%$ EG.
\end{abstract}

Keyword: vitrification, Dimethyl sulfoxide, Ethylene glycol, viability of oocytes 


\section{Pendahuluan}

Daya hidup oosit terbatas mengingat setelah oosit diovulasikan akan mengalami degradasi sehingga jika dibiarkan untuk waktu yang terlalu lama pasca ovulasi, menyebabkan Untuk mencegah kerusakan oosit, diperlukan teknologi penyimpanan oosit agar daya fertilitasnya dapat diperpanjang. Kriopreservasi sudah lama dilakukan sebagai upaya untuk menyimpan sekaligus mengawetkan oosit dari betina dewasa untuk jangka waktu yang lama (Gook, 2011). Dengan kryopreservasi, oosit akan mengalami dorman dan dihambat metabolismenya dalam kurun waktu yang sudah ditentukan tanpa mematikan sel. Oosit dapat melanjutkan perkembangannya kembali setelah dilakukan proses warming. Vitrifikasi merupakan salah satu metode kriopreservasi dengan menggunakan waktu yang sangat cepat dan konsentrasi krioprotektan yang tinggi sehingga tidak terbentuk kristal es baik intraseluler maupun ekstraseluler (Silber, 2017). Kondisi demikian tentunya akan mengurangi kerusakan sel akibat proses kriopreservasi sehingga sel dapat dipertahankan kelangsungan hidupnya (Djuwita, 2001).

Proses vitrifikasi memerlukan krioprotektan sebagai pelindung sel selama proses pembekuan. Ethylen glikol (EG) dan dimetil sulfoksida (DMSO) sudah digunakan sebagai kryoprotektan bertahun-tahun dan terbukti dapat digunakan dalam vitrifikasi sel telur dan embrio sapi (Vajta et al., 1998). Sudah dilaporkan dalam studi yang dilakukan oleh Newton dan Subramoniam (1996), bahwa EG memiliki dampak sitotoksik yang rendah terhadap embrio, sedangkan studi yang dilakukan Kartberg et al., 2008 menyebutkan bahwa DMSO tidak menyebabkan kerusakan membrane sel dan kematian pada embrio. Namun sangat disayangkan, karena terbatasnya penelitian tentang konsentrasi optimal DMSO jika dikombinasikan dengan EG untuk digunakan sebagai media vitrifikasi.

Berdasarkan uraian tersebut, maka tujuan dari penelitian ini adalah untuk mengevaluasi viabilitas oosit pasca vitrifikasi dengan menggunakan kombinasi DMSO dan EG dengan dua level konsentrasi yang berbeda. Melalui penelitian ini, diharapkan: 1). Dapat oosit tidak akan dapat difertilisasi. Oosit yang berasal dari ovarium sapi pada suhu $37{ }^{\circ} \mathrm{C}$ selama 8 jam telah terbukti akan mengalami penurunan performa pada tahap pembelahan maupun tahap blastosis (Yang et al., 1990). dievaluasi efektifitas vitrifikasi dengan menggunakan media yang mengandung variasi DMSO dan EG, serta 2) Dapat diketahui perbandingan kuantitas dan kualitas oosit dalam konsentrasi media vitrifikasi yang diujikan.

\section{Materi dan Metode}

Penelitian dilaksanakan di Laboratorium Riset dan Bioteknologi, Fakultas Peternakan, Universitas Padjadjaran periode September 2016-Desember 2016.

\section{Bahan}

Oosit yang diperoleh dari ovarium domba lokal yang dipotong di tempat pemotongan hewan (TPH) setempat, $\mathrm{NaCl}$ fisiologis 0,9\%, fetal bovine serum (FBS), tissue culture media 199 (TCM 199), follicle stimulating hormone (FSH), luteinizing hormone (LH), dimethyl sulfoxide (DMSO), ethylene glycol (EG), sukrosa, Na Bicarbonat, Phosphate Buffer Saline (PBS). Koleksi oosit menggunakan hemistraw (home made) saat vitrifikasi, kemudian diamati dengan mikroskop stereo dan inverted.

\section{Media yang digunakan}

Media maturase oosit yang digunakan adalah media TCM199 (Sigma, USA) yang ditambahkan FBS 10\%, $10 \mathrm{IU} / \mathrm{ml}$ pregnant mare serum gonadotrophin (PMSG) (Intergonan, Intervet Deutschland $\mathrm{GmbH}), 10 \mathrm{IU} / \mathrm{ml}$ human chorionic gonadotrophin (hCG) (Chorulon, Intervet international B.V. Boxmeer-Holland) dan $50 \mu \mathrm{g} / \mathrm{ml}$ gentamycin (Sigma, USA). Media yang digunakan untuk equilibrasi oosit adalah $8,5 \% \mathrm{v} / \mathrm{v}$ DMSO $+8,5 \% \mathrm{v} / \mathrm{v}$ EG dalam media dasar PBS yang telah ditambahkan dengan FBS $20 \%$. Media vitrifikasi yang digunakan adalah $17 \% \mathrm{v} / \mathrm{v} \mathrm{DMSO}+17 \% \mathrm{v} / \mathrm{v} \mathrm{EG}+0.65 \mathrm{M}$ sukrosa dalam media dasar PBS yang telah ditambahkan dengan FBS 20\%.

\section{Metode Pengambilan Sampel Koleksi Ovarium dan Koleksi Oosit}

Metode koleksi oosit yang digunakan pada penelitian ini adalah sesuai dengan metode 
yang digunakan oleh Widyastuti dan Rasad (2015). Ovarium dicuci dengan media koleksi, setelah itu dipotong untuk mendapatkan oosit. Oosit yang didapat kemudian dicuci dengan $\mathrm{NaCl}$ fisiologis $0,9 \%$ sebanyak 2 kali, sedangkan pencucian terakhir dengan media maturasi TCM 199. Objek penelitian adalah oosit yang mempunyai sel-sel kumulus komplek lebih dari dua lapis dengan sitoplasma homogen.

\section{Proses Maturasi Oosit}

Proses maturasi oosit yang digunakan pada penelitian ini adalah sesuai dengan metode yang digunakan oleh Widyastuti et al., 2017a. Oosit dimaturasi secara in vitro dalam media maturasi selama 24 jam. Oosit dicuci sebanyak 3 kali dengan media dPBS, kemudian oosit dipindahkan ke dalam $100 \mu \mathrm{L}$ drop media pematangan yang dibuat pada petridish steril lalu ditutup dengan mineral oil. Setiap drop media pematangan berisi sekitar yaitu 10 oosit. Selanjutnya oosit diinkubasi selama 24-26 jam dalam inkubator pada suhu $38,5^{\circ} \mathrm{C}, 5 \% \mathrm{CO}_{2}$ dan kelembaban 95\%. Selanjutnya dilakukan evaluasi terhadap kematangan oosit. Tingkat kematangan oosit dievaluasi dengan melihat munculnya polar body pertama. Selanjutnya dilakukan vitrifikasi pada oosit yang telah matang.

\section{Metode Vitrifikasi dan Warming (pencairan) Oosit} Analisa Statistik

Penelitian ini menggunakan metode eksperimental laboratorium. Perlakuan yang dicobakan adalah vitrifikasi oosit domba, menggunakan media vitrifikasi dengan dua konsentrasi yang berbeda. Data dianalisa dengan menggunakan SPSS software versi 16 (SPSS Inc, Chicago, IL, USA). Persentase oosit hidup setelah vitrifikasi-warming dianalisa dengan t-student test, perbedaan signifikan apabila $\mathrm{P}<0,05$.

\section{Hasil dan Pembahasan \\ Penelitian tentang vitrifikasi oosit dengan berbagai macam metode sudah dilakukan di banyak studi untuk mengetahui seberapa jauh oosit dapat bertahan hidup.}

\section{Proses vitrifikasi (simpan beku) dan warming Oosit}

Oosit yang telah matang divitrifikasi dengan menggunakan carrier hemistraw (homemade). Oosit diequilibrasi selama 10 menit di dalam larutan equilibrasi, kemudian dipaparkan ke dalam medium vitrifikasi selama 30 detik. Selanjutnya oosit di load ke dalam hemistraw. Alat ini kemudian dipaparkan secara langsung ke dalam liquid nitrogen $\left(\mathrm{LN}_{2}\right)$ dan kemudian disimpan di dalam tanki $\mathrm{LN}_{2}$ sebelum dilakukan warming kembali. Semua proses vitrifikasi tersebut dilakukan di suhu ruang.

Oosit dicairkan kembali dengan cara memasukkan carrier (hemistraw) ke dalam 3 serial media pencairan yang berbeda; $0.5 \mathrm{M}$ sukrosa, $0.25 \mathrm{M}$ sukrosa dan $0.15 \mathrm{M}$ sukrosa. Setelah warming, oosit dikultur dalam incubator $\mathrm{CO}_{2}$ selama 3-4 jam untuk melihat apakah oosit hidup (viabilitas) atau mati (lisis) (Widyastuti et al., 2017b).

\section{Evaluasi Viabilitas Oosit}

Evaluasi viabilitas oosit domba setelah vitrifikasi dilakukan dengan mengkultur secara in vitro pada media kultur selama 3 jam untuk melihat re-ekspansi sel-sel, keutuhan sitoplasma, dan kondisi zona pelusida (Winangun et al., 2017).

Vitrifikasi bertujuan untuk mencegah proses pengkrisatalan es dalam sel akibat adanya cairan intra dan ekstraselular dalam proses pembekuan. Pengkristalan es dalam sel akan menyebabkan sel mudah pecah dan akhirnya menjadi lysis. Maka dari itu, diperlukan medium penyimpanan sel yang mampu menghindari proses pengkristalan es tersebut terjadi. Oleh karenanya, medium penyimpanan sel adalah salah satu faktor krusial dalam mempengaruhi daya tahan oosit selama proses vitrifikasi berlangsung. Dalam penilitian ini, digunakan kombinasi DMSO dan EG sebagai medium penyimpanan oosit selama proses vitrifikasi berlangsung, Viabilitas oosit setelah vitrifikasiwarming dapat dilihat pada Tabel 1 . 
Tabel 1. Data Viabilitas atau Persentase Hidup Oosit Pasca Vitrifikasi-Warming

\begin{tabular}{lcc}
\hline Media Vitrifikasi & $\begin{array}{c}\text { Jumlah oosit } \\
(\mathrm{n})\end{array}$ & $\begin{array}{c}\text { Persentase oosit hidup } \\
\text { pasca vitrifikasi Warming } \\
(\%)\end{array}$ \\
\cline { 2 - 3 } & & $28\left(50,00 \pm 3,55 \%^{\mathrm{a}}\right)$ \\
$17 \% \mathrm{DMSO}+15 \% \mathrm{EG}$ & 55 & $21\left(75,00 \pm 5,89 \%{ }^{\mathrm{b})}\right.$ \\
\hline
\end{tabular}

Keterangan: Superscrip ${ }^{\text {a,b }}$ berbeda nyata pada kolom yang sama

Secara statistik, dapat diamati bahwa dari 55 oosit yang diujikan, terdapat 28 oosit yang mampu bertahan dalam media kriopreservasi mengandung $15 \%$ DMSO $+15 \%$ EG. Sedangkan dalam media vitrifikasi yang mengandung $17 \%$ DMSO $+17 \%$ EGdiperoleh hasil 21 dari 31 oosit yang diujikan mampu bertahan hidup. Hal ini menunjukkan bahwa viabilitas oosit dalam krioprotektan $17 \%$ DMSO $+17 \%$ EG atau lebih tinggi $2.34 \%$ dibandingkan dengan $15 \% \mathrm{EG}+15 \%$ DMSO.

Dalam media 17\% DMSO $+17 \%$ EG, konsentrasi baik DMSO dan EG, lebih tinggi dibandingkan dengan satu media pembanding lainnya, sehingga yang masuk ke dalam oosit lebih banyak dan lebih mampu meningkatkan permeabilitas membran sel dan mempermudah EG, yang memiliki berat molekul rendah, masuk ke dalam sel oosit. Ketika keduanya sudah masuk ke dalam oosit, hal ini akan menyebabkan lebih banyak cairan intra dan ekstraseluler tertarik keluar, sehingga proses pengkristalan akibat pembekuan dapat ditekan. Sampai sejauh ini, belum ada studi yang membandingkan kombinasi DMSO dan EG dengan dua konsentrasi yang berbeda terhadap oosit domba. Penelitian yang sudah ada hanya membahas viabilitas oosit mamalia yang dilakukan oleh Pamungkas (2010) dan oosit manusia oleh Chen et al., 2010).

Pada prinsipnya, DMSO dan EG merupakan larutan hipertonik yang akan menyebabkan adanya perbedaan tekanan osmotik dalam jaringan, sehingga cairan intra dan extraselular akan keluar dan digantikan dengan DMSO dan EG. Setelah diekuilibrasi dalam waktu yang singkat, volume cairan dalam sel akan kembali seperti sedia kala tanpa harus merusak struktur sel. Dengan demikian, potensi pembentukan es dalam sel akan berkurang, struktur sel tidak mudah pecah akibat pembekuan, derajat pengerutan sel akan dibatasi, konsentrasi elektrolit dalam dan luar sel akan relatif rendah (FAO).

EG sudah banyak dipakai dalam metode vitrifikasi karena memiliki berat molekul yang rendah dan juga cenderung kurang toksik terhadap oosit mamalia ataupun manusia (Zhu, S.E., et al. 1993). DMSO dapat penetrasi ke dalam sel, membentuk lapisan kaca dan meningkatkan laju permeabilitas ketika digabungkan dengan EG. DMSO merupakan krioprotektan permeabel lambat yang jika digabungkan dengan EG dapat saling melengkapi dalam meningkatkan daya hidup sel seperti yang telah dilakukan oleh Mukaida et al. (2003) terhadap embrio.

Namun, ketepatan konsentrasi keduanya saat digunakan sebagai media vitrifikasi akan mempengaruhi daya hidup oosit. Belum diketahui pasti apakah jika konsentrasi keduanya ditingkatkan akan memberikan efek yang lebih baik atau tidak. Maka dari itu, diharapkan ada studi lebih lanjut untuk menjawab pertanyaan tersebut.

\section{Kesimpulan}

Dari studi yang telah dilakukan dapat disimpulkan bahwa 17\% DMSO+17\% EG dapat meningkatkan viabilitas oosit pasca vitrifikasi jika dibandingkan dengan 15\% DMSO $+15 \%$ EG.

\section{Daftar Pustaka}

Chen, ZQ., Ming, T.X., and Nielsen, H.I. 2010. Maturation arrest of human oocytes at germinal vesicle stage. Journal of Human Reproduction Science (3):153-7. doi: 10.4103/09741208.74161 .

Djuwita, I. 2001. Kajian morfologis dan fungsi biologis oosit domba setelah 
kriopreservasi dengan metode vitrifikasi. Disertasi. Sekolah Pascasarjana Institut Pertanian Bogor, Bogor. $104 \mathrm{hlm}$.

FAO. Basic Principles of Cryopreservation. Fao.org.

Gook, D.A. 2011. History of oocyte cryopreservation. Reproduction Biomed Online. 23(3):281-9. doi: 10.1016/j.rbmo.2010.10.018. Epub 2010 Nov 12.

Kartberg AJ1, Hambiliki F, Arvidsson T, Stavreus-Evers A, Svalander P. 2008. Vitrification with DMSO protects embryo membrane integrity better than solutions without DMSO. Reprod Biomed Online. 17(3):37884.

Mukaida, T., Takahashi, K., Kasai M. et al. 2003. Blastocyst cryopreservation: ultrarapid vitrification using cryoloop technique. Reprod BioMed Online; 6: 221-225.

Newton S.S., Subramoniam T. 1996. Cryoprotectant toxicity in penaeid prawn embryos. Cryobiology. $33: 172-177$.

Pamungkas, F. A. 2010. Pemanfaatan Metode

Vitrifikasi untuk Kriopreservasi Oosit Mamalia. Wartazoa..20 (20).

Silber, S. 2017. Chapter 13 Human Ovarian Tissue Vitrification. Methods in Molecular Biology. 1568:177-194. doi: 10.1007/978-1-4939-6828-2 13.

Vajta, G., Holm, P., Kuwayama, M., et al. 1998. Open Pulled Straw (OPS) vitrification: a new way to reduce cryoinjuries of bovine ova and embryos. Molecular Reproduction and Development. 51(1):53-8. Widyastuti dan Rasad. 2015. Tingkat kematangan inti oosit sapi setelah 24 jam presevasi ovarium. Agripet : Vol (15) No.2 : 72-78.

Widyastuti, R., M.R.A.A .Syamsunarno, T. Saili, A. Boediono. 2017a. Oocyte quality and subsequent in vitro maturation of sheep oocyte-cumulus complex from ovary with presence and absence of corpus luteum. Proceedings of The Veterinary Medicine International Conference. Surabaya. KnE Life Sciences 3 (6): 166-174.

Widyastuti R, Khoirinaya C, Ridlo MR, Syamsunarno MRAA. 2017b. Perbandingan Viabilitas Oosit pasca Vitrifikasi pada Konsentrasi Sukrosa yang berbeda. Majalah Kedokteran Bandung: 49(4): 252-258

Winangun K, Widyastuti R, Syamsunarno MRAA. 2017. Perbandingan viabilitas oosit domba pasca vitrifikasi dengan menggunakan hemistraw dan cryotop. Jurnal Agripet:17 (2): 75-80.

Yang NS, Lu KH, Gordon I. 1990. In vitro fertilization (IVF) and culture (IVC) of bovine oocytes from ovaries storage. Theriogenology, 33:352.

Zhu SE1, Kasai M, Otoge H, Sakurai T, Machida T. 1993. Cryopreservation of expanded mouse blastocysts by vitrification in ethylene glycol-based solutions. J Reprod Fertil. May;98(1):139 